the permanent secretary of the Treasury thought it necessary to invite representatives of various sections of civil service opinion to an informal discussion.

WHILE informal discussions may serve a useful purpose, it is worth while asking why no representative was included of the professional and scientific interests in the civil service, of which the Institution is the accredited spokesman, although among those invited was the representative of at least one smaller body representative of non-technical interests. Official representations from the Institution were put aside on the ground that the conversations were 'informal', although the attempt was afterwards made to treat as negotiators the four individuals selected. We could have perhaps understood, even if we had deplored, this failure to acknowledge the existence of the specialist interest in the civil service, were it not for the fact that the Institution's position has already been recognised by its special direct representation on the National Council to which we have referred. It is a curious revelation of official psychology that it should be thought unnecessary to consult with this distinctive and, we claim, this essential element in the modern civil service, upon a major issue affecting specialists in common with other types of civil servants.

\section{Taxes on Books in Australia}

Mr. Lyons' Government in Australia, "having given very earnest consideration to requests that the taxation burden on educational literature should be lightened", has, we learn from an announcement in the Melbourne Argus of June 3, granted certain exemptions which, though satisfactory so far as they go, are very meagre concessions compared with the case against a tax on books of any kind. Primage duty at port of entry will no longer be charged on books and periodicals imported by or for the State public libraries, the National Library at Canberra, and the libraries of the several universities. Hymn books, prayer books, and literature published by or issued under the authority of the League of Nations will also be admitted free; and so will historical records in print, picture, or manuscript imported by or for libraries. Unfortunately, the sales tax still remains.

\section{Alleged Psychic Phenomena}

In a long letter to Nature, Mr. Harry Price, the honorary director of the National Laboratory of Psychical Research, has commented upon the review of Dr. Osty"s book, "Les Pouvoirs inconnus de l'esprit sur la matière", published in these columns on June 25. He states that both Mr. Malcolm and Mr. Lambert changed their views regarding the alleged psychic phenomena produced by Mr. Rudi Schneider, although Mr. Lambert, according to the letter quoted by Mr. Price, merely says that, in his opinion, there was no possibility of the medium having produced the phenomena fraudulently. It is clear that these later opinions were not based on personal observation but from reading the record of others. Again, Mr. Price dis- misses, without apparently realising its relevance, the incident of the match-box, suggesting, as it does, the invasion of the séance room from without, suspected for so long by competent observers. Moreover, in upholding the genuineness of Mr. Schneider's phenomena, Mr. Price declares that the opinions quoted in the review were from persons who had a priori convictions that the mediumship was a fraud-a statement in support of which he offers no evidence and which is almost certainly contrary to fact.

\section{Physics and Psychics}

IN conclusion, Mr. Price emphasises his own views on the independent examination of mediums by remarking that it has been his practice to introduce them to men of science of repute in order to encourage independent investigation; and in this he claims some considerable success. It must be remarked, however, that the invitations issued by the late $\mathrm{Dr}$. von Schrenck-Notzing, the late Dr. G. Geley, and by Mr. Price were not for the purpose of granting any true scientific inquiry. The persons invited were merely privileged spectators of phenomena produced under conditions over which they had little control and in circumstances where accuracy of observation was almost impossible. Mr. Price claims that the phenomena described by Dr. Osty have been duplicated by him with similar results, and that when Mr. Schneider is in London in September of this year he will be pleased to invite assistance from physicists. What is wanted, however, is not the mere presence of experts at the experiments of others in an atmosphere which, rightly or wrongly, cannot fail to arouse suspicion. It is an arrangement whereby the alleged influence at a distance, which, it is claimed, can be measured and detected by purely physical means, is so measured and examined by independent observers in their own laboratories, with their own apparatus, and under those conditions most favourable to accurate scrutiny.

\section{Early Man in America}

IT is a not infrequent occurrence in America for discoveries to be announced which, it is said, afford indubitable evidence of the existence of man on that continent in very early times. Usually this evidence takes the form of one or more stone implements associated with the bones of extinct mammals, such as an elephant, in deposits held to be Pleistocene and in conditions which are claimed to justify the conclusion that the implements and fossils are contemporary. Usually it appears on further investigation that it is either impossible to verify the exact position, relative or absolute, of the finds, or an application of the strict canon of evidence reveals some flaw which vitiates the conclusion. American palæontologists and archæologists, however, continue to examine with patient determination every claim that is reported, and at the same time to examine diligently areas in which the deposits are such as might well afford the evidence which is sought. One such area is the State of Nebraska, which, in view of its geographical relation to the glacial area of the ice age, is regarded by

No. 3272, VoL. 130] 